\title{
R2 - PRODUCTION OF IMMUNOGLOBULIN Y SPECIFIC FOR HUMAN ROTAVIRUS FOR DIAGNOSTIC METHOD AND IMMUNOTHERAPY
}

Gentil Arthur Lins Bentes Mendonça de $\operatorname{Vasconcelos~}^{1}$; Natália Maria Lanzarini ${ }^{1}$; Juliana Rodrigues Guimarães ${ }^{1}$; Alexandre dos Santos da Silva ${ }^{1}$; Eduardo de Mello Volotão ${ }^{1}$; Marcelo Alves Pinto ${ }^{1,2}$

${ }^{1}$ Instituto Oswaldo Cruz/FIOCRUZ, Lab. de Desenvolvimento Tecnológico em Virologia, Rio de Janeiro, Brasil

${ }^{2}$ Escola de Medicina Veterinária, C.C.S./UNIFESO, Teresópolis, Brasil

Objectives: In this study we describe the production, purification and characterization of IgY anti-rotavirus A group (RV-A) antibody proceeded in immunized hens for use in diagnostic methods and immunotherapy. The IgY antibodies production against rotavirus is justified by several advantages presented by this antibody such as easy achievement, low cost, wide scale production and more appropriate method about the bioethics aspect.

Methods: Six hens were divided in two groups (I and II) and immunized at intervals of one month with different protocols: Group I - received three immunizations with human and simian RV-A associated with incomplete Freund adjuvant (IFA) and oligodesoxinucleotides that have C-fosfatoguanosin (CpG-ODN); Group II - received three immunizations with IFA and CpG-ODN (negative control). The study was approved in Ethics Commission in Animals Tract-UNIFESO ( $\left.n^{\circ} 0331 / 11\right)$. The eggs were collected and the yolks were purified by precipitation in polyethylene glycol (PEG) method. The IgY was quantified by Lowry method and characterized by the techniques of electrophoresis in polyacrylamide gel with sodium dodecyl sulfate (SDS-PAGE) and Western Blotting. A neutralization assay in vitro was performed to evaluate the specificity and the ideal concentration of purified IgY for neutralize the rotavirus in MA-104 cell culture.

Results: The hens had no change in growth kinetics by reason of immunizations and their egg laying was high, with 358 eggs laid during thirteen weeks. The purification of IgY with polyethylene glycol was efficient and reached high concentration. In group I, the average of concentration was $37,5 \mathrm{mg} / \mathrm{mL}$ and the peak occurred at $10^{\text {th }}$ week with 
$59,5 \mathrm{mg} / \mathrm{mL}$ of total protein. In group II, the average was $27,5 \mathrm{mg} / \mathrm{mL}$ and the peak occurred at $12^{\text {th }}$ week with $52,5 \mathrm{mg} / \mathrm{mL}$. In SDS-PAGE we confirmed that the $\operatorname{IgY}$ was the protein purified analyzing your molecular weight profile, $70 \mathrm{kDa}$ of high chain and $25 \mathrm{kDa}$ of light chain. The Western Blotting confirmed the specificity of IgY to rotavirus. In neutralization assay in vitro, the specificity also was demonstrated, but the ideal concentration of IgY anti-rotavirus was obtained. Until the antibody concentration of $1,5 \mathrm{mg} / \mathrm{mL}$ neutralized totally the virus, in lower concentrations the virus replicate.

Conclusion: The characterization methods of $\operatorname{IgY}$ demonstrated specificity to the rotavirus antigens and efficacy in rotavirus neutralization in culture cells. The IgY antirotavirus was successfully produced, and their use in diagnostic methods and immunotherapy need to be tested in the future. 